\title{
GRANULOMETRY OF THE FLUVIAL DEPOSITS AND SEDIMENTATION CONDITIONS IN THE VALGEJÕGI VALLEY, NORTH ESTONIA
}

\author{
Tiit HANG $^{a}$ and Ewa NIEDZIALKOWSKA ${ }^{b}$
}

a Eesti Teaduste Akadeemia Geoloogia Instituut (Institute of Geology, Estonian Academy of Sciences), Estonia pst. 7, EE-0100 Tallinn, Eesti (Estonia)

b Instytut Geografii PAN, Zaklad Geomorfologii i Hydrologii (Institute of Geography, Polish Academy of Sciences), 31-018 Kraków, ul. Sw. Jana 22, Polska (Poland)

Presented by A. Miidel

Received February 2, 1994; accepted March 25, 1994

Abstract. Two different methods of counting grain-size indices (according to Johnson's deviation and formulas of Folk \& Ward) were used to explain sedimentation environment in the Valgejõgi Valley, North Estonia. Both methods revealed similar tendencies as demonstrated in three types of diagrams.

Slight differences in the mean size of channel and overbank deposits are due to the homogeneity of the mainly glaciolacustrine source material. The flow environment in the channel is described but it was impossible to distinguish any subfacies within the overbank sediments.

Key words: grain size, grain-size indices, fluvial deposits, fluvial sedimentation environment, Estonia.

\section{INTRODUCTION}

From the geological point of view the Valgejõgi Valley is one of the most interesting valleys in North Estonia (Fig. 1). The $77 \mathrm{~km}$ long Valgejõgi River belongs to the basin of the Gulf of Finland. It begins from Lake Porkuni at the Pandivere Upland. The general orientation of the river, as with most North-Estonian rivers, is from SE to NW, correlating with the orientation of the tectonic faults (Мийдел, 1966). The descent of the Valgejõgi River is $106.6 \mathrm{~m}$ (main gradient $1.5 \%$ ) of which about $60 \%$ is in the $17 \mathrm{~km}$ long lower reach (with a gradient of $3.5 \%$ ). In its upper part the river flows on the North-Estonian Plain, where the Quaternary cover has notable thickness only within the limits of ice marginal zones. Descending from the North-Estonian Klint (a limestone escarpment), the Valgejõgi River forms a $1.2 \mathrm{~m}$ high waterfall at Nõmmeveski where the $400 \mathrm{~m}$ long and $50-60 \mathrm{~m}$ wide canyon-like valley is eroded into Cambrian and Ordovician rocks. At the lower reach the Valgejõgi Valley is eroded into glaciolacustrine sands and gravel, glaciofluvial gravel, and till. In this part of the valley there are eight terraces on the slopes and the width of floodplain is up to $300 \mathrm{~m}$ (Miidel, 1961). At the lower reach the meandering river has an about $5 \mathrm{~m}$ deep and up to $10 \mathrm{~m}$ wide channel. 


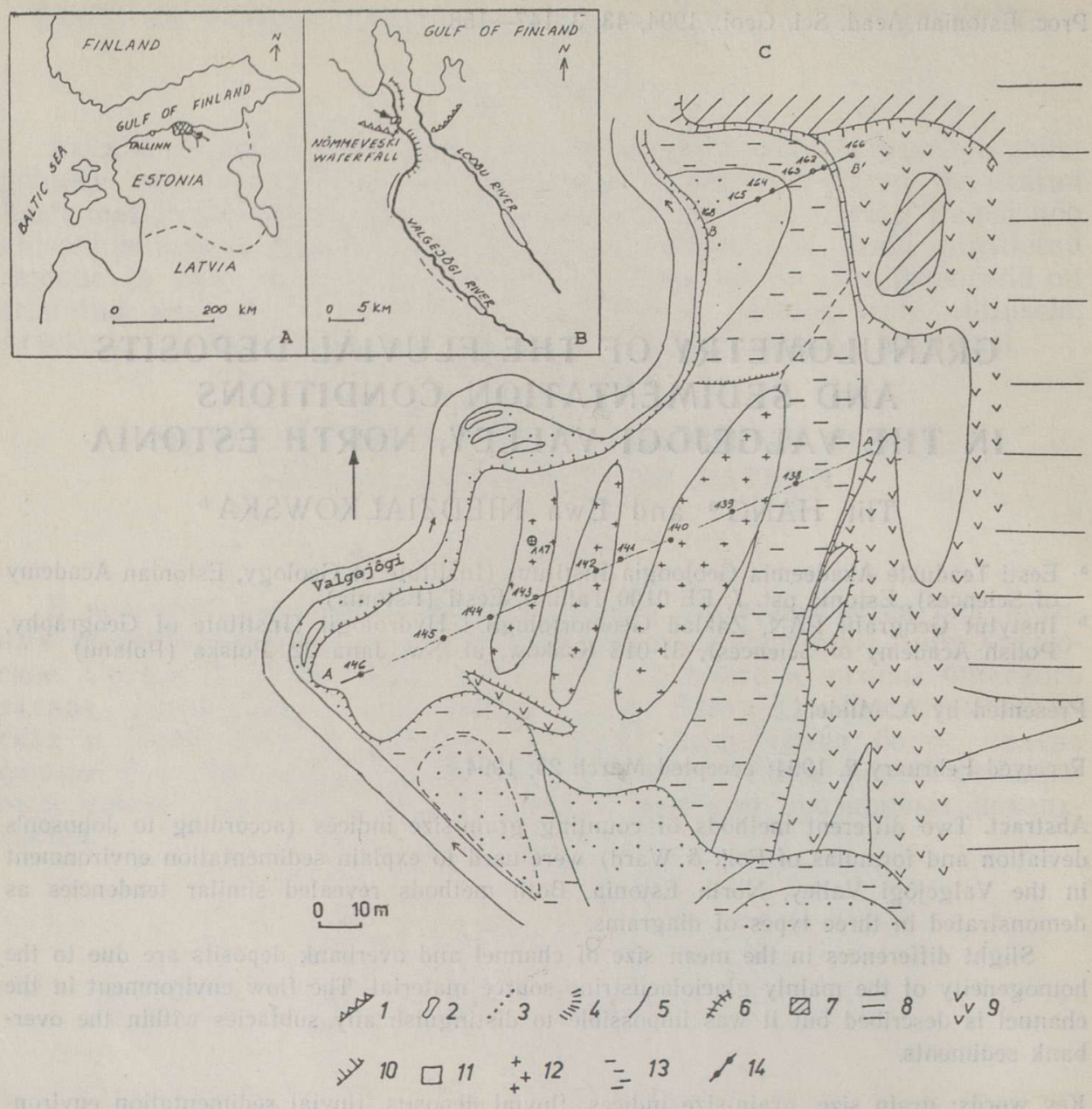

Fig. 1. Investigation area.

A Location of Valgejõgi Valley.

$B$ Valgejögi Valley against the background of main geomorphic units (after Miidel, 1961).

C Detailed geomorphological sketch of the research area of the Valgejōgi Valley. 1 North-Estonian Klint, 2 Holocene lake, 3 morphologically poorly formed valley, $4 \mathrm{~V}$-shaped valley, 5 floodplain valley without terraces, 6 floodplain valley with terraces, 7 location of the studied area, 8 valley slope, 9 high terrace level, 10 terrace edge, 11 floodplain, 12 higher parts of the floodplain, 13 abandoned channel, 14 cross-section line and boreholes.

The evolution of the Valgejōgi Valley is closely connected with the tectonic uplift and with the evolution of the Baltic Sea during Late- and Post-Glacial time. An elongation of the valley as well as the formation of terraces took place towards the Gulf of Finland in accordance with the lowering of the base level, the Baltic Sea.

The investigated area of the Valgejõgi Valley is located about $500 \mathrm{~m}$ downstream of the Nõmmeveski waterfall (Fig. 1B). This part of the valley is about $20 \mathrm{~m}$ deep and it has two terraces on the slopes. The up to $200 \mathrm{~m}$ wide floodplain is bounded by terraces on the right. On the left it is bounded by the valley slope, cut into the glaciofluvial deposits (Fig. $1 C$ ). The relative height of the floodplain is $3.5-4.5 \mathrm{~m}$ above the water 
level and the floodplain is partly submerged only during extremely strong floods. The relief of the floodplain is undulated (Fig. $1 C$ ). Paleomeanders are preserved under the terrace edge on the right side of the valley.

Various grain-size interpretations have been used to distinguish the genetic types of deposits. The main sedimentation environment has definite characteristics, which are distinctly visible especially on scatter diagrams. Sedimentation characteristics have been used by many authors (Vaskovska, 1971; Gradowski \& Ratajczak, 1980) to explain the sedimentation environment. Also, long-term paleohydrodynamic conditions in different valleys have been reconstructed (Baker \& Penteado-Orellana, 1978; Antczak, 1986; Mycielska-Dowgiałlo, 1987).

A number of formulas are known for calculating grain-size indices. Numerous papers have been published on the effectiveness of these formulas and the possibilities of using them in practice (Stochlak, 1973; Pieczka, 1969; Grzegorczyk, 1970; Visher, 1978; Racinowski \& Szczypek, 1985; Gradzinski et al., 1986).

In the present paper an attempt is made to describe the fluvial sediments and the conditions of their deposition in the Valgejõgi Valley based on both grain-size analysis and calculated grain-size indices.

\section{METHODS}

The records of 15 boreholes in 2 cross-sections on the floodplain and 1 borehole (No. 117) located in the central part of the floodplain were analysed (Fig. 1). The geological cross profile of the floodplain is characterized (Fig. 2). Eleven samples were collected from lithologically different layers of core No. 117. From the remaining cores, 44 samples were taken only from the different genetic units. This material was the subject of the grain-size analysis. From the 55 samples, 11 were analysed in parallel in the laboratories of the Institute of Geology of the Estonian Academy of Sciences in Tallinn and the Department of Geomorphology and Hydrology, Institute of Geography of the Polish Academy of Sciences in Krakow. Besides the sieve analysis used for sand and gravel separation, the hydrometer technique was applied for sand and silt separation at the Institute of Geology. The following grain sizes (in $\mathrm{mm}$ ) were determined: $0.001-0.005 ; 0.005-0.01 ; 0.01-0.05 ; 0.05-0.063 ; 0.063-0.08 ; 0.08-0.1$; $0.1-0.125 ; \quad 0.125-0.16 ; \quad 0.16-0.20 ; \quad 0.20-0.25 ; \quad 0.25-0.315 ; \quad 0.315-$ $0.4 ; 0.4-0.5 ; 0.5-0.63 ; 0.63-0.8 ; 0.8-1.0 ; 1.0-1.25 ; 1.25-1.6 ; 1.6-2.0$; $2.0-2.5 ; 2.5-3.15 ; 3.15-4.0 ; 4.0-6.3$.

For calculating statistical parameters Johnson's deviations (Johnson, 1978) were used as a statistical method at the Institute of Geology. Also, the method of kvantils after Slifker and Shapiro (1980) was used. According to Johnson's deviations kvantils $(P) 10 \%, 25 \%, 75 \%$, and $90 \%$ are the base on which different characteristics are calculated as follows:

Median diameter:

$$
M d=P 50
$$

Sorting (detsil sorting):

$$
\sigma=\frac{P 90-P 10}{2}
$$

Skewness (kvartil skewness):

$$
S k=\frac{P 25+P 75-2 \times 50}{2}
$$


Kurtosis (kvartil kurtosis):

$$
K=\frac{P 90-P 10}{P 75-P 25}-1
$$

According to the calculated characteristics the scatter diagrams of the median diameter $(M d)$ versus detsil sorting or standard deviation $(\sigma)$, kvartil skewness $(S k)$, and kvartil kurtosis $(K)$ were constructed (Fig. 3).

At the Institute of Geography of the Polish Academy of Sciences the grain-size distribution was analysed by sieving and hydrometric techniques. Particles from $16 \mathrm{~mm}(-4.0 \Phi)$ to $0.125 \mathrm{~mm}(3.0 \Phi)$ in diameter were shaken through sieves spaced at $0.5 \Phi$ intervals. And for hydrometry, these intervals were at about $1 \Phi$. From the results of grain-size analyses the following parameters were calculated according to the formulas of Folk and Ward (1957):

Mean size:

$$
M z=\frac{\Phi 16+\Phi 50+\Phi 84}{3}
$$

Inclusive graphic standard deviation:

$$
\sigma_{\mathrm{I}}=\frac{\Phi 84-\Phi 16}{4}-\frac{\Phi 95-\Phi 5}{6.6}
$$

Inclusive graphic skewness:

$$
S k_{1}=\frac{\Phi 16+\Phi 84-2 \Phi 50}{2(\Phi 84-\Phi 16)}+\frac{\Phi 5+\Phi 95-2 \Phi 50}{2(\Phi 95-\Phi 5)} ;
$$

Graphic kurtosis:

$$
K_{\mathrm{G}}=\frac{\Phi 95-\Phi 5}{2.44(\Phi 75-\Phi 25)}
$$

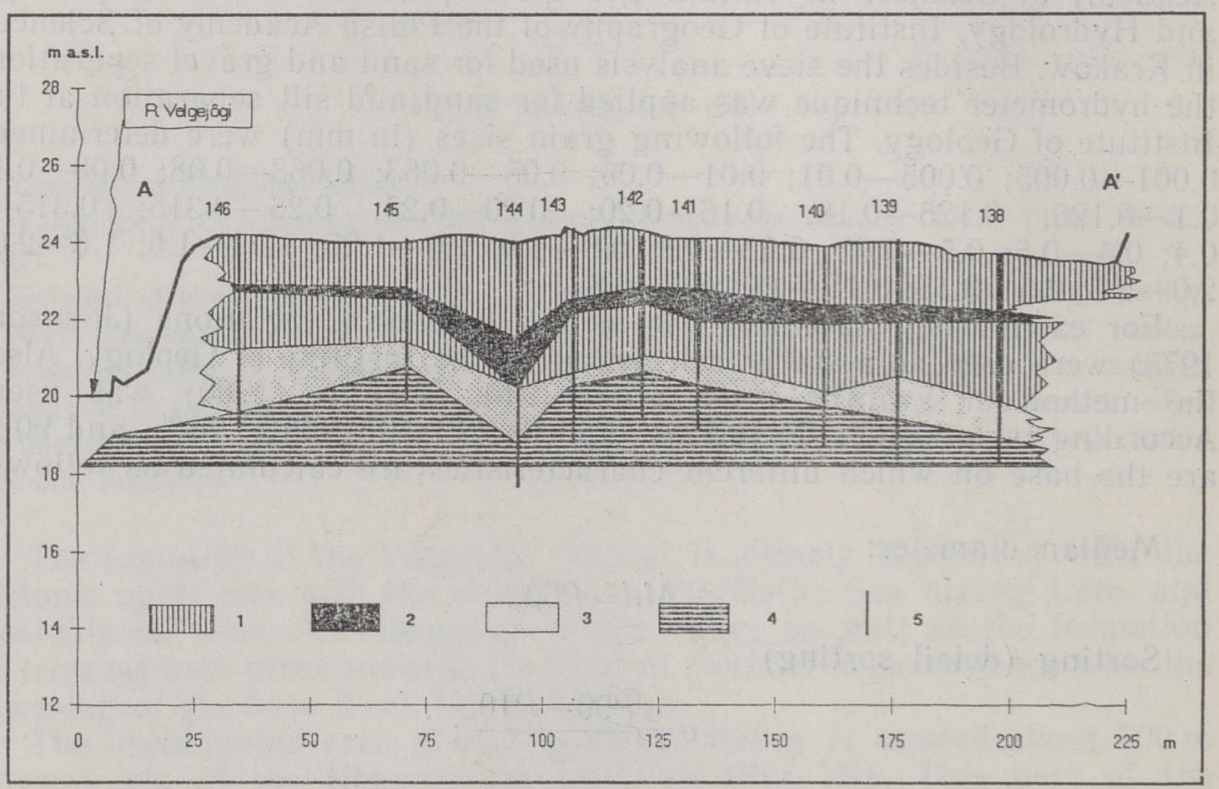

Fig. 2. Cross-section $A-A^{\prime}$.

1 overbank deposits, 2 oxbow-like deposits, 3 channel deposits, 4 glaciolacustrine deposits, 5 boreholes. 


\section{RESULTS}

The main analysed section $\left(A-A^{\prime}\right)$ crosses the floodplain inside the meander (Fig. 1C). It is $220 \mathrm{~m}$ long and is represented by ten corings (Fig. 2). Two different types of fluvial sediments were distinguished. These are overbank and channel deposits, which were underlain by LateGlacial varved clays (Fig. 2). The overbank sediments reach a depth of $3.5-4.0 \mathrm{~m}$ and are underlain by $0.2-0.4 \mathrm{~m}$ thick organic rich sediments (Fig. 2). The thickness of the sandy-gravel channel sediments varies between $0.5-1.5 \mathrm{~m}$ (Fig. 2). The thickness of the basic glaciolacustrine sediments was not estimated.

As the sediments in all cores are quite similar, a detailed description of only one borehole (No. 117) is presented below:
$0.00-0.25 \mathrm{~m}$ - sandy soil (sample 1 )
$0.25-0.40 \mathrm{~m}$ - fine sand, light (sample 2)
$0.40-0.55 \mathrm{~m}$ - fine sand, bright brown (sample 3 )
$0.55-0.65 \mathrm{~m}$ - fine sand, bright brown with light spots, with horizontal layers (up to $1 \mathrm{~cm}$ thick) of organic matter (sample 4)
$0.65-0.85 \mathrm{~m}$ - silty sand, dark brown (samples 5 and 6 )
$0.85-1.25 \mathrm{~m}$ - rusty spot sand, fine-grained at the top and coarse at the bottom of the layer (sample 7 )
$1.25-1.85 \mathrm{~m}$ - medium-grained sand, light (sample 8)
1.85-2.05 m - medium- and coarse-grained sand, light (sample 9)
2.05-2.60 $\mathrm{m}$ - coarse sand with gravel, cross-bedded sediments containing organic matter (samples 10, 11)
$2.60-3.50 \mathrm{~m}-$ glaciolacustrine varved sediments

The grain-size parameters were calculated for 11 samples from this core applying two different methods. Using calculations based on Johnson's deviation the diagrams of median diameter versus detsil sorting, kvartil skewness, and kvartil kurtosis were constructed (Fig. $3 A$ ). The results calculated after Folk and Ward's formulas were used for constructing diagrams of mean size versus inclusive graphic standard deviation, inclusive graphic skewness, and graphic kurtosis (Fig. $3 B$ ). As expected, these two methods gave very different values of grain-size indices. However, in both cases similar regularities were observed. In both diagrams the samples $(1-11)$ fell clearly into three groups (Fig. 3). In the following interpretation, verbal classification and numerical limits for sorting, skewness, and kurtosis after Folk and Ward (1957) were used.

One of the groups (Nos. $1-7$ ) is characterized by a small mean size $(M z=2.4-3.5 \Phi)$ as well as a small median diameter $(M d=2.2-3.0 \Phi)$. At the same time these sediments are well to poorly sorted $\left(\sigma_{\mathrm{I}}=0.45-1.75\right.$; $\sigma=0.5-1.85$ ) and they have symmetrical or positive skewness and leptokurtic to highly leptokurtic distribution (Fig. 3).

The second group consists of two samples (Nos. 8 and 9) with mean sizes of $1.15 \Phi$ and $0.75 \Phi$ and median diameters of $1.25 \Phi$ and $1.0 \Phi$ (Fig. 3). In Fig. $3 B$ these samples are moderately to poorly sorted, and in Fig. $3 A$ poorly sorted. The material under discussion has negative skewness in both diagrams and is mesokurtic to highly platykurtic in Fig. $3 B$ and mesokurtic in Fig. $3 A$.

The third, coarse-grained group, shows clearly in Fig. $3 B$. Samples 10 and 11 , with mean sizes of $-1.7 \Phi$ and $-1.25 \Phi$, are very poorly sorted. These samples are characterized by symmetrical and positive skewness and they are highly platykurtic (Fig. $3 B$ ). In Fig. $3 A$ the third group is not very clearly distinguishable. The characteristics of sample 11 differ greatly from those of sample 10 . Both samples are poorly sorted; sample 


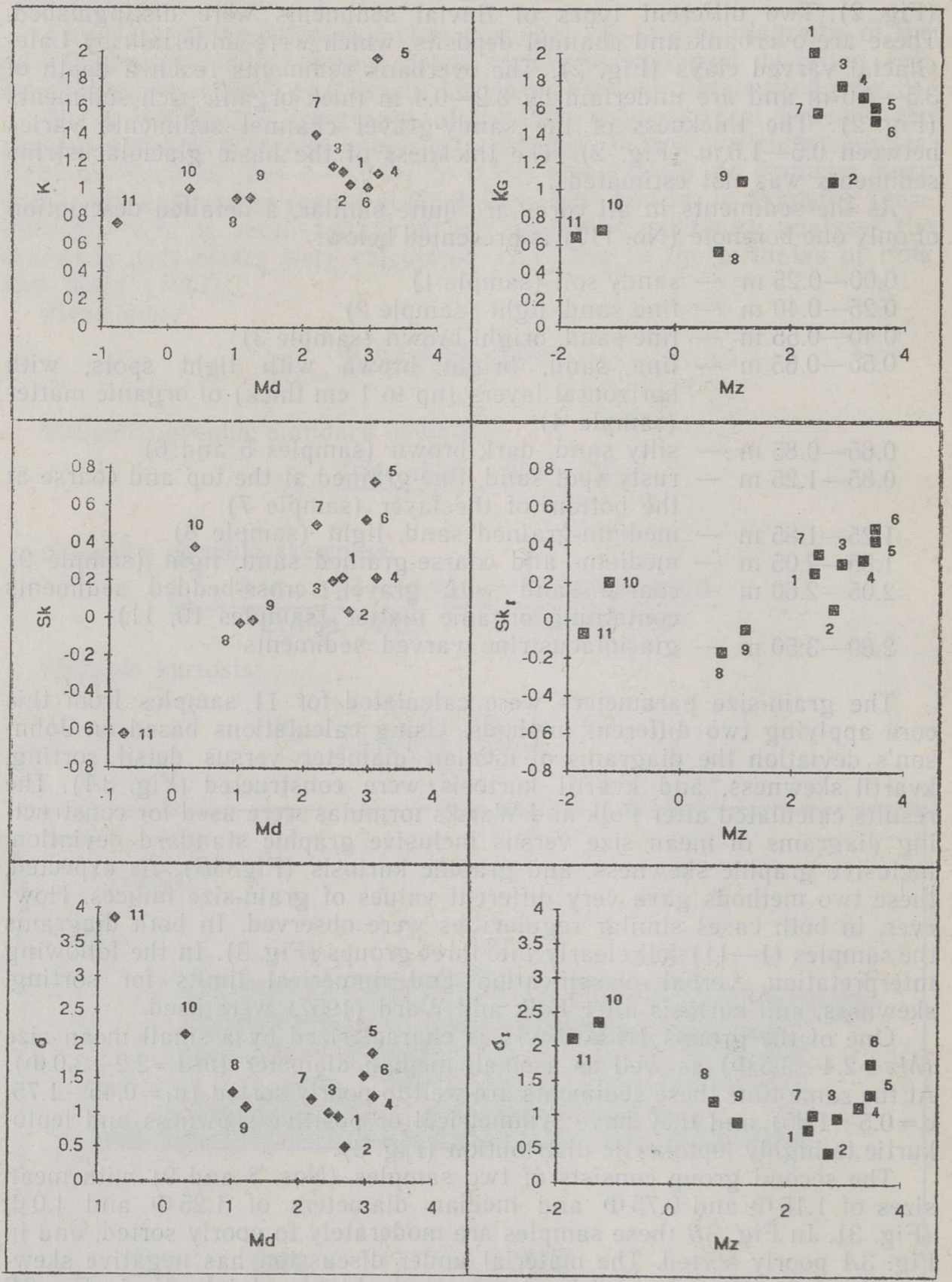

Fig. 3. Scatter diagrams.

A Median diameter $(M d)$ versus kvartil kurtosis $(K)$, kvartil skewness $(S k)$, and standard deviation $(\sigma)$.

$B$ Mean size $(M z)$ versus graphic kurtosis $\left(K_{\mathrm{G}}\right)$, inclusive graphic skewness $\left(S k_{1}\right)$, and inclusive graphic standard deviation $\left(\sigma_{1}\right)$. 
10 has positive and sample 11 negative skewness, and accordingly they are meso- and platykurtic (Fig. $3 A$ ).

The two last-mentioned groups (samples 10 and 11 , and 8 and 9) are undoubtedly channel sediments. Samples 8 and 9 belong to the top part of the point bar, where the material is usually finer (Levey, 1978; Bridge \& Diemer, 1983). The first group of samples (Nos. $1-7$ ) belong to overbank deposits. These deposits do not contain the finest material and it is difficult to say to which type of overbank deposits they belong. We explain it as a material deposited on the floodplain covered with plants. This is the reason for the formation of organic-rich layers (paleosoils). Similar sediments are described by Klimek (1989) on the floodplain of the San River (Bieszczady Mountains). The overbank sediments become finer with increasing depth (Nos. 1-6) while the sorting becomes poorer (Fig. $3 B$ ).

Only calculations by Johnson's deviations were used to calculate similar characteristics for 40 samples from the cores of the main cross section (Fig. 4). On the constructed scatter diagrams the points are clearly divided into two main groups (Fig. 4). One is the group of fine sediments with median diameters from 1.65 to $3.75 \Phi$. The second group consists of coarse material with median diameters ranging from -1.7 to $1.1 \Phi$ (Fig. 4).

The first group of samples is clearly seen in all the three diagrams. These deposits are characterized by similar values of the median diameter, sorting, skewness, and kurtosis. They are well to poorly sorted $(\sigma=0.5-1.4)$. Most of them have symmetrical skewness and values of kurtosis of about 1.0 (Fig. 4). These features reflect a very moderate and uniform environment of transport and sedimentation. This material was probably transported in graded suspension, because there is a small difference in the median diameter $(\max 1.5 \Phi)$ and the finest sediments are absent. This group of samples consists of overbank sediments. Some channel sediments falling into this group are explained by several possibilities of sedimentation of fine material in places without current flow or during flood in the active channel (Froehlich, 1975; Teisseyre, 1988).

The second group of samples is characterized on the three types of diagrams by different patterns. This reflects changing environments of transport and sedimentation of the material. The group consists of coarse (median diameter between -1.7 and $1.1 \Phi$ ) and poorly sorted material (Fig. 4).

On the scatter diagram of median diameter versus standard deviation two subgroups are seen (Fig. 4). One of them, subgroup $A$, is highly coarse-grained $(-1.70$ to $-0.5 \Phi)$, poorly sorted, and platykurtic. The environment of sedimentation of such sediments is probably associated with a high flow velocity and with the transportation of material as bed load. Poor sorting and platykurtic distribution show that the material contains particles with different diameters. The conditions of the deposition of such material are typical of the main part of the channel where deposition is very fast during flood time. Part of these samples have highly positive skewness, which means that the flow velocity decelerated and the sedimentation of fine-grained particles began. The above-described conditions can appear in the uppermost part of a bar or in a shallow part of a channel.

The material of subgroup $B$, with a smaller median diameter $(0.0-$ $1.0 \Phi)$, is poorly and very poorly sorted and it is characterized by symmetrical or negative skewness and leptokurtic distribution. The sedimentation of such material probably took place under a moderate flow velocity in the channel.

Detailed investigation shows that samples from core No. 117 (Fig. 3A) are very similar to those of groups I and IIB (Fig. 4). On the one hand 


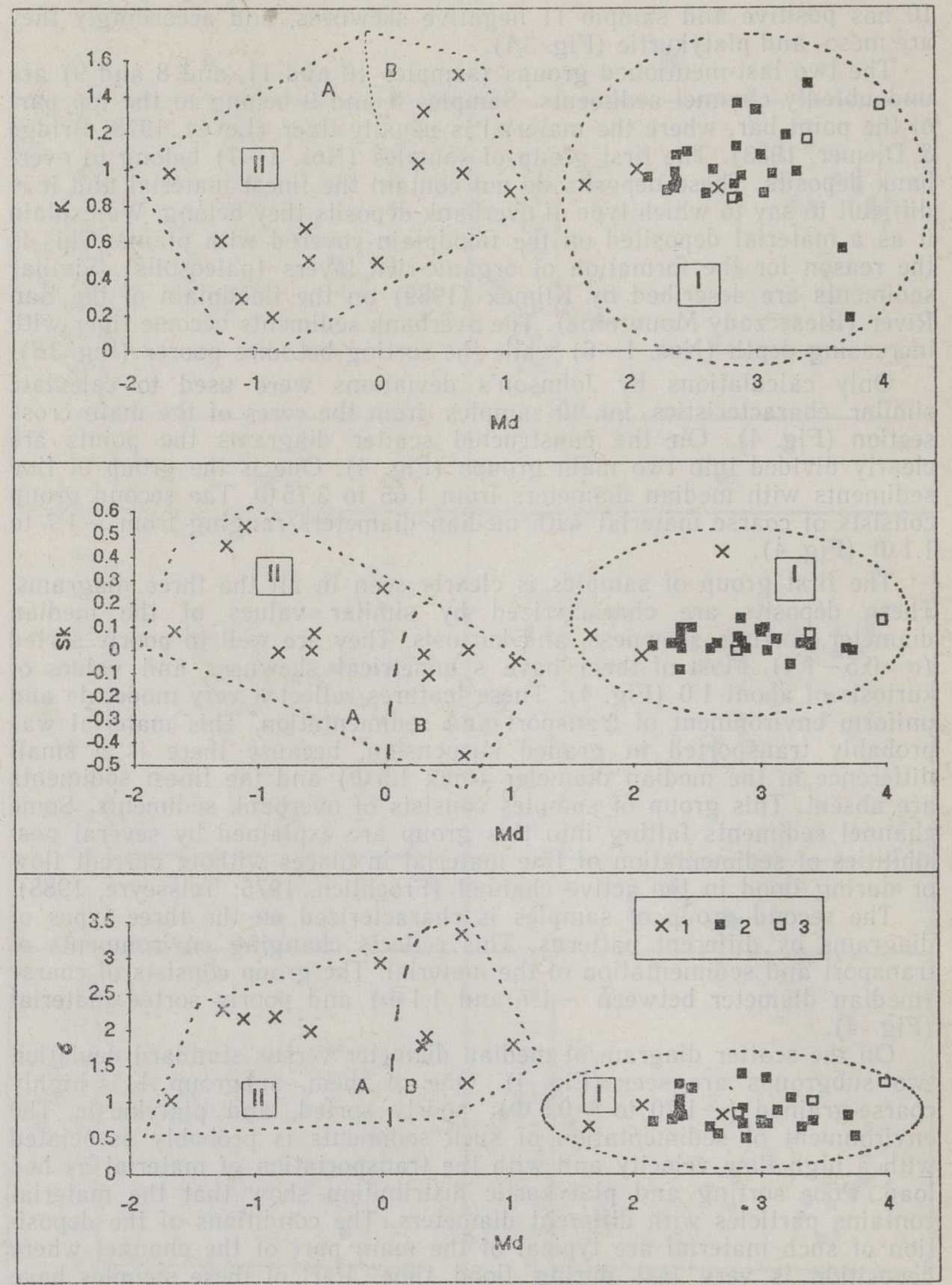

Fig. 4. Scatter diagrams of median diameter $(M d)$ versus kvartil kurtosis $(K)$, kvartil skewness $(S k)$, and standard deviation $(\sigma)$.

1 channel deposits, 2 overbank deposits, 3 glaciolacustrine deposits. Subgroups of samples are distinguished by dashed lines. 
it is explained by quite a small number of samples falling into subgroup $A$, and on the other hand by a small amount of data from one core.

The diagrams in Figs. 3 and 4 are considered to be typical of fluvial sediments (Folk \& Ward, 1957; Niedzialkowska, 1991). Various conditions in the channel and floodplain are reflected in these diagrams, though the statistical collection was very small.

The possibility of distinguishing some subfacies within the overbank sediments was also checked. Probably the conditions in the Valgejongi Valley (underlying glaciolacustrine deposits, small gradient, relatively low velocities, and the like) were not able to produce notable differences in granulometry. This is confirmed by examples from Poland. In similar geological and geomorphological conditions (Polish lowlands) in the Słupia Valley (Florek in Alexandrowicz et al., 1990) and in the Parseta Valley (Zwolinski, 1985) the floodplain consists of similar sandy sediments (even their mean sizes are similar: 1.5-3.0Ф). It is possible that the Quaternary deposits, especially sandy glacial and glaciolacustrine ones, had a certain importance as a source material.

\section{CONCLUSIONS}

The two methods of analysis and counting used gave different values of grain-size indices. At the same time, the main tendencies are similar in both cases on three types of diagrams (Fig. 3).

Small variability of the source material (glaciolacustrine deposits) and the low gradient of the river are the main reasons for small differences in the mean size of channel and overbank deposits. Nevertheless, they have different sorting.

On scatter diagrams it is possible to distinguish overbank and channel facies of alluvial sediments. In the channel sediments it is possible to make conclusions about the flow environment in the channel during the deposition of these sediments thanks to relatively rapidly changing flow conditions and accordingly remarkable differences in grain size.

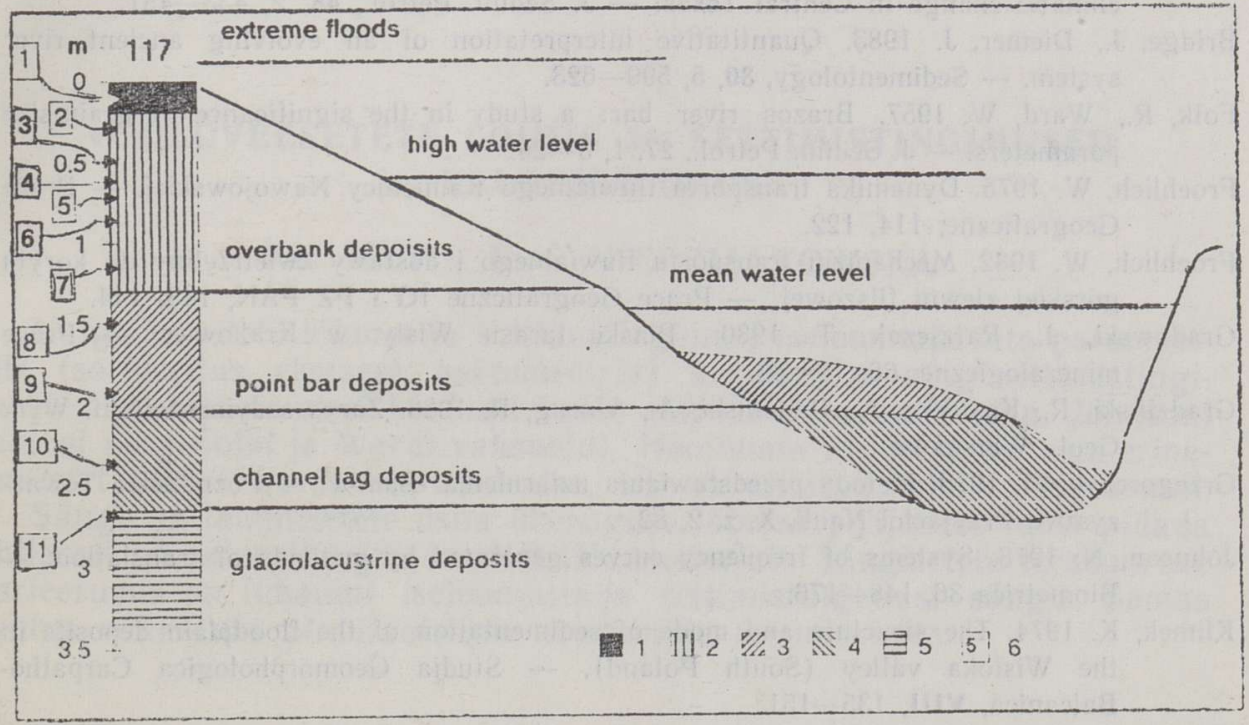

Fig. 5. Geological profile from core No. 117 and the supposed conditions of deposition. 1 soil, 2 fine sand, 3 coarse sand, 4 sandy gravel, 5 varved clay, 6 samples. 
In case of small differences in diameter, like the overbank deposits of the Valgejõgi, it is impossible to distinguish any subfacies within these sediments. Such sediments are considered to have been deposited on floodplain covered with grass (Klimek, 1989).

As mentioned above, the overbank deposits in core No. 117 become coarser towards the floodplain surface. This is explained by the need of increasingly more flow energy during floods to bring the material to the surface of the floodplain, the height of which is also rising (Klimek, 1974; Froehlich, 1982). With the increasing flow energy coarse material is transported. The cross section in Fig. 5 shows where the material of different samples from core No. 117, investigated in detail, might have been deposited.

\section{ACKNOWLEDGEMENTS}

All laboratory analysis in Tallinn were made by Aivo Lepland. He, Yuri Vassilyev, and Aavo Miidel helped with the fieldwork. Critical reading of the manuscript by Leszek Starkel (Krakow) and Anto Raukas (Tallinn) has been very valuable. Helle Kukk corrected the language. To all these people we are very grateful.

\section{REFERENCES}

Alexandrowicz, S. W., Florek, W., Zaborowska, K., Zachowicz, J. 1990. The Slupia upper floodplain in the vicinity of Slupsk, Pomerania, Poland. - Quaestiones Geographicae, $11 / 12$.

Antczak, B. 1986. Transformacja układu koryta i zanik bifurkacji Warty. - Wyd. Naukowe UAM, Seria Geogr., 35, 110.

Baker, V., Penteado-Orellana, M. 1978. Fluvial sedimentation conditions and Quaternary climatic change in Central Texas. - J. Sedim. Petrol., 48, 2, 433-451.

Bridge, J., Diemer, J. 1983. Quantitative interpretation of an evolving ancient river system. - Sedimentology, 30, 5, 599-623.

Folk, R., Ward, W. 1957. Brazos river bar: a study in the significance of grain-size parameters. - J. Sedim. Petrol., 27, 1, 3-26.

Froehlich, W. 1975. Dynamika transportu fluwialnego Kamienicy Nawojowskiej. - Prace Geograficzne, 114, 122.

Froehlich, W. 1982. Mechanizm transportu fluwialnego i dostawy zwietrzeliny do koryta górskiej zlewni fliszowej. - Prace Geograficzne IG i PZ PAN, 143, 144.

Gradowski, J., Ratajczak, T. 1980. Piaski tarasu Wisly w Krakowie. - Prace mineralogíczne, 66, 19-33.

Gradziński, R., Kostecka, A., Radomski, A., Unrug, R. 1986. Zarys sedymentologii. Wyd. Geol., Warszawa.

Grzegorczyk, M. 1970. Metody przedstawiania uziarnienia osadów. - Poznańskie Towarzystwo Przyjaciół Nauk, $\mathbf{X}, \mathrm{z}, 2,82$.

Johnson, N. 1978. Systems of frequency curves generated by methods of translation. Biometrica 36, 148-176.

Klimek, K. 1974. The structure and mode of sedimentation of the floodplain deposits in the Wisłoka valley (South Poland). - Studia Geomorphologica CarpathoBalcanica, VIII, 135-151.

Klimek, K. 1989. Floodplains activity during floods in small mountain valleys, the Bieszczady Mts., the Carpathians, Poland, - Quaẹtiones Geographicae, Specią! issue $2,93-100$, 
Levey, R. 1978. Bed-form distribution and internal stratification of coarse-grained point bars, Upper Congaree river. S.C. - In: Miall, A. D. (ed.). Fluvial Sedimentology. Canadian Society of Petroleum Geologists, Calgary. Memoir 5, 105-127.

Miidel, A. 1961. Holotseensete orgude geoloogilise arenemise seaduspärasusi Põhja-Eestis. - Eesti NSV TA Geol. Inst. Uurimused, VII, 147-157.

Mycielska-Dowgiallo, E. 1987. Morphogenesis of Vistula valley in northern part of Sandomierz Basin in the Late Glacial and Holocene. - Geographical studies, Special issue $4,115-129$.

Niedzialkowska, E. 1991. The textural diversity of Upper Quaternary fluvial deposits in the Carpathian foreland. - Geographical Studies, Special issue 6, 119-146.

Pieczka, F. 1969. Wskaźniki liczbowe i graficzne struktury osadów okruchowych oraz rezimu hydrodynamicznego morskiego środowiska sedymentacyjnego. - Zeszyty Naukowe Politechniki Gdańskiej, Budownictwo Wodne, XIII, 52-146.

Racinowski, R., Szczypek, T. 1985. Prezentacija i interpretacja wyników badań uziarnienia osadów czwartorzedowych. - Skrypty Uniwersytetu Slaskiego, 359, 143.

Slifker, J., Shapiro, S. 1980. The Johnson system. Selection and parameter estimation. Technometrics, 22, 2, 239-246.

Stochlak, J. 1973. Mozliwość interpretacji genezy osadów drobnoklastycznych na podstawie statystycznych wskażników uziarnienia. - Przeglad Geologiczny, XXI, 12, 649-658.

Teisseyre, A. 1988. Mady dolin sudeckich. Cześć 11: Wybrane zagadnienia metotologiczne. - Geologica Sudetica, XXIII, 1, 65-101.

Vaskovska, E. 1971. Litologicko-faciálna charakteristika genetických typow kvartérnych sedimentov Záhorskiej Nižiny. - Geologicke prace, 55, 5-45.

Visher, G. 1978. Grain-size frequency studies. - In: Fairbridge, R. W., Bourgeois, J. (eds.). The Encyclopedia of Sedimentology. Dowden, Huchinson \& Ross, Inc., Stroudsburg, Pennsylvania, 370-374.

Zwoliński, Z. 1985. Sedymentacja osadów przyrostu pionowego na terasie zalewowej Parsety. - Badania Fizjograficzne nad Polska Zachodnia, XXXV, ser. A, 205238.

Мийдел А. 1966. О связи направлений долин с тектонической трещиноватостью на территории Эстонской ССР. - In: Eesti Geograafia Seltsi Aastaraamat 1964/ 1965. Valgus, Tallinn, 18-33.

\title{
VOOLUVEESETETE LOIMIS JA SETTIMISTINGIMUSED VALGEJOEE ORUS
}

\author{
Tiit HANG, Ewa NIEDZIAŁKOWSKA
}

Valgejõe setete lõimist ja settimistingimusi iseloomustavate parameetrite (sorteeritus, ekstsess, asümmeetria) arvutamisel ning settimistingimuste iseloomustamisel kasutati kahte statistilist meetodit (nn. Johnsoni jaotusi ning Folki ja Wardi valemeid). Hoolimata arvutustulemuste erinevusest täheldati sarnaseid tendentse, mis on esitatud kolmel diagrammil.

Sängi- ja lammisetete üsna ühesuguse lõimise põhjuseks tuleb pidada ühtlaselt peeneteralist jääjärvelist lähtematerjali. Sängisetete terasuuruse varieeruvus on lubanud iseloomustada settimistingimusi sängis. Samas osutus võimatuks alamfaatsieste eristamine lammisetetes. 


\section{ГРАНУЛОМЕТРИЧЕСКИЙ СОСТАВ И УСЛОВИЯ СЕДИМЕНТАЦИИ ФЛЮВИАЛЬНЫХ ОТЛОЖЕНИИ В ДОЛИНЕ Р. ВАЛГЕИЫГИ, СЕВЕРНАЯ ЭСТОНИЯ}

ТиЙТ ХАНГ, Ева НИЕДЗИАЛКОВСКА

С использованием метода распределения Джонсона и формул Фолка и Варда охарактеризованы гранулометрический состав и условия седиментации флювиальных отложений в долине р. Валгейыги. Несмотря на различия в результатах вычислений, установлены сходные тенденции, которые представлены на трех типах диаграмм.

Относительно сходный гранулометрический состав пойменных и русловых фаций обусловлен мелкоозернистостью размываемых лимногляциальных отложений. По распределению гранулометрического состава русловой фации определены условия седиментации в русле. Фациальное разделение пойменных отложений не представилось возможным. 